\title{
Heat Treatments Applied to Martensitic Stainless Steels and the Results Obtained
}

\author{
Marius Valeriu COMICI \\ Transilvania University of Brasov, Romania, comici.valeriu.marius@unitbv.ro \\ Ioan GIACOMELLI \\ Transilvania University of Brasov, Romania, giacomelli@unitbv.ro \\ Maria STOICANESCU \\ Transilvania University of Brasov, Romania, stoican.m@unitbv.ro
}

\begin{abstract}
For this paper, various heat treatment operations were performed on 40Cr130 steel with a view to the structures obtained and some mechanical properties. Of these, the hardness and shock resistance were determined under different test conditions. Significant variations in fracture energies were found depending on both the structural state and the test temperature.
\end{abstract}

\section{Keywords}

heat treatment, martensitic stainless steels, mechanical properties

\section{Introduction}

The 40Cr130 steel, part of the martensitic stainless steels, is intended for the production of various items for both industrial and consumer use; thus, it can be used in the manufacture of a wide range of bearings, parts subject to wear, but also for other parts such as springs, bushings, instrument engineering parts, precision instruments, etc. [1]. Each of these areas of use requires a certain set of mechanical, physical, and chemical characteristics $[3,4,5]$. These can be achieved by applying an appropriate heat treatment $[2,3,4]$.

The chemical composition of this steel is shown in Table 1.

Table 1 . The chemical composition of $40 \mathrm{Cr} 130$ steel

\begin{tabular}{|c|c|c|c|c|c|c|c|}
\hline \multirow{2}{*}{ Material type } & \multicolumn{7}{|c|}{ Chemical composition, in \% } \\
\cline { 2 - 8 } & $\mathrm{C}$ & $\mathrm{Cr}$ & $\mathrm{Si}$ & $\mathrm{Mn}$ & $\mathrm{P}(\mathrm{max})$ & $\mathrm{S}(\mathrm{max})$ & Mo \\
\hline $40 \mathrm{Cr} 130$ & 0.42 & 13.5 & 1.0 & 1.0 & 0.045 & 0.03 & 0.2 \\
\hline
\end{tabular}

\section{Work Method and Results}

The samples of this steel underwent heat treatment operations as shown in Table 2.

Table 2. Heat treatment

\begin{tabular}{|c|c|c|c|c|c|}
\hline \multirow{3}{*}{ Material type } & \multicolumn{5}{|c|}{ Applied heat treatment } \\
\hline & \multirow[b]{2}{*}{ Annealing $\left[{ }^{\circ}\right]$} & \multicolumn{2}{|c|}{ Quenching } & \multirow{2}{*}{$\begin{array}{c}\text { Tempering } \\
\text { Temperature } \\
\left.{ }^{\circ}\right]\end{array}$} & \multirow[b]{2}{*}{$\begin{array}{c}\text { Hardness } \\
\text { [HRC }]\end{array}$} \\
\hline & & $\begin{array}{c}\text { Temperature } \\
{\left[{ }^{\circ}\right]}\end{array}$ & $\begin{array}{l}\text { Cooling } \\
\text { medium }\end{array}$ & & \\
\hline \multirow{7}{*}{$40 \mathrm{Cr} 130$} & 750 & - & - & - & 24 \\
\hline & \multirow{6}{*}{750} & \multirow{2}{*}{950} & \multirow{2}{*}{ oil } & 150 & 51 \\
\hline & & & & 510 & 52.8 \\
\hline & & \multirow{2}{*}{1000} & \multirow{2}{*}{ oil } & 150 & 49 \\
\hline & & & & 510 & 50 \\
\hline & & \multirow{2}{*}{1050} & \multirow{2}{*}{ oil } & 150 & 54 \\
\hline & & & & 510 & 52.5 \\
\hline
\end{tabular}


RECENT, Vol. 21, no. 1(60), 2020

The metallographic structures obtained are shown in Figures 1, 2 and 3.

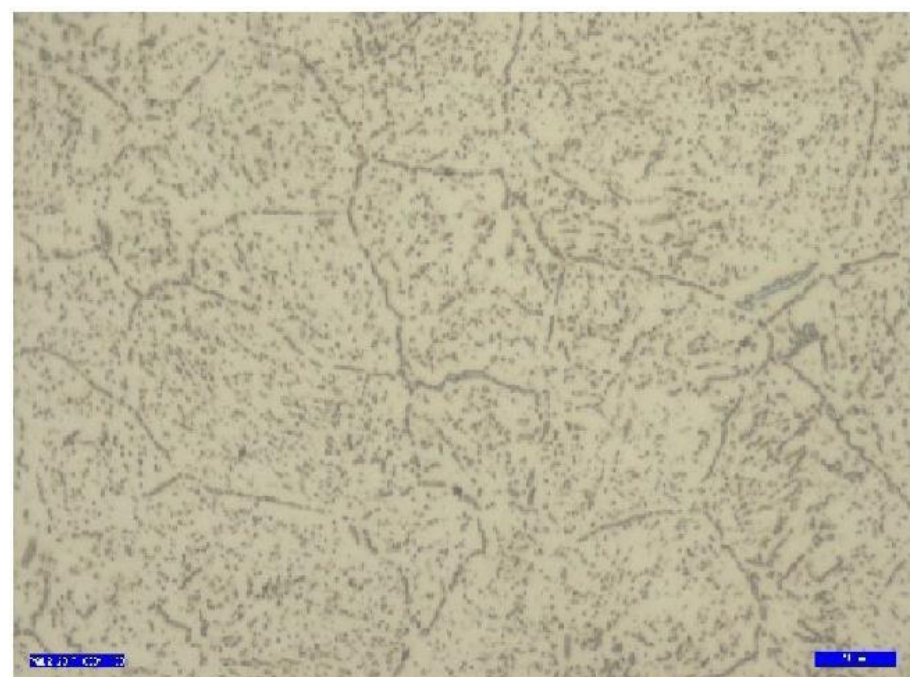

Fig. 1. 40Cr130 in annealed state. Attack Nital. 1000:1

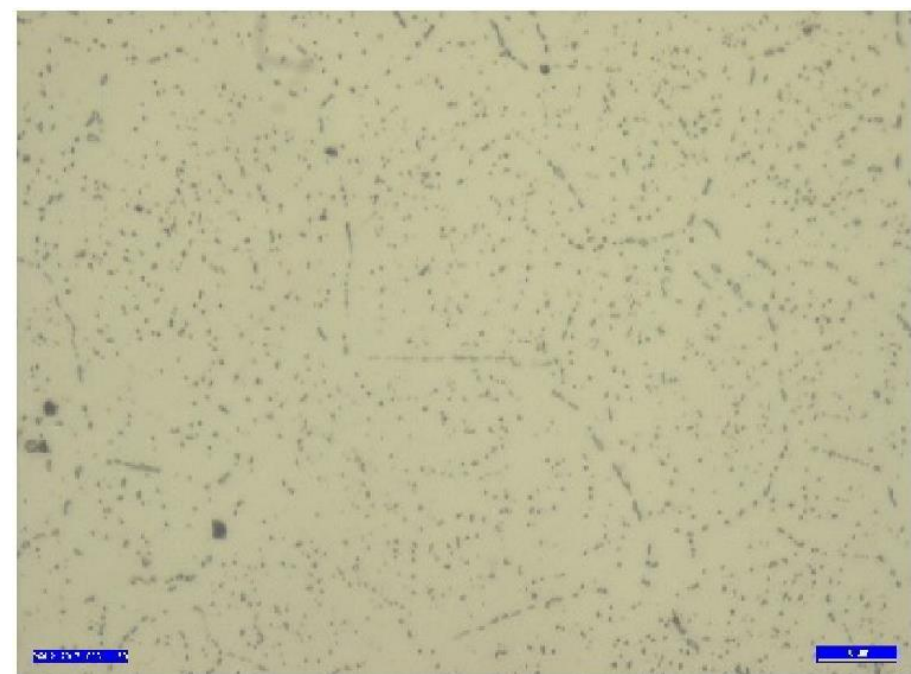

Fig. 2. 40Cr130 hardened at $1050^{\circ} \mathrm{C}$, held for 1.5 hours, cooled in oil. Attack Nital. 1000:1

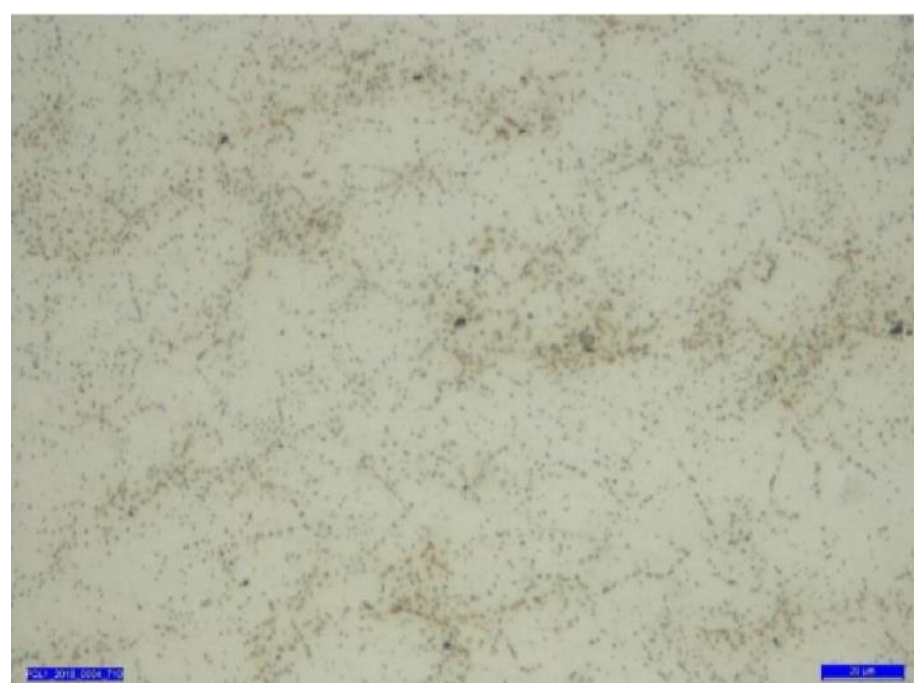

Fig. 3. $40 \mathrm{Cr} 130$ hardened to $1050{ }^{\circ} \mathrm{C}$, held for 1.5 hours and tempered at $510{ }^{\circ} \mathrm{C}$. Attack Nital. 1000:1 
RECENT, Vol. 21, no. 1(60), 2020

The structure of the steels shown in the micrographs above features ferrite and carbides (Figure 1), martensite and carbides (Figure 2) and tempered martensite, bainite and carbides (Figure 3).

The shock resistance of $40 \mathrm{Cr} 130$ was studied on resilience specimens with square cross-section and U-shaped notch. These specimens underwent a wide range of heat treatment operations and followed by the measurement of the fracture energy.

The heat treatment regimens and the test results are presented in Table 3.

Table 3. Heat treatment regimens and the results obtained

\begin{tabular}{|c|c|c|c|c|c|}
\hline \multirow[b]{2}{*}{ Item } & \multirow{2}{*}{$\begin{array}{l}\text { Material } \\
\text { type }\end{array}$} & \multicolumn{3}{|c|}{ Heat treatment type } & \multirow{2}{*}{$\begin{array}{l}\text { Resilience } \\
\mathrm{KCU}\left[\mathrm{J} / \mathrm{cm}^{2}\right]\end{array}$} \\
\hline & & $\begin{array}{c}\text { Temperature } \\
{\left[{ }^{\circ}\right]}\end{array}$ & $\begin{array}{c}\text { Holding } \\
\text { time [hours] }\end{array}$ & Cooling medium & \\
\hline 1 & \multirow{4}{*}{$40 \operatorname{Cr} 130$} & 770 & 2.5 & $\begin{array}{l}\text { In the furnace down to } 300{ }^{\circ} \mathrm{C} \\
\text { and afterwards in the air }\end{array}$ & 60 \\
\hline 2 & & 770 & 1.5 & oil & 45 \\
\hline 3 & & 700 & 1.5 & oil & 18 \\
\hline 4 & & 650 & 1.5 & oil & 16 \\
\hline
\end{tabular}

The results above highlight the major influence on the shock resistance of the heat regime applied to the material. Thus, with the increase of the heating temperature, the energy necessary for breaking also increases.

The cooling medium applied after the holding period also has a substantial influence. Compared to the cooling in the furnace, the faster cooling in oil causes a decrease in resilience (Table 4). The internal stresses that occur during the cooling in oil and the prevention of the separation of chromium carbides have an impact in this regard.

Table 4. Resilience values following the heat treatment

\begin{tabular}{|c|c|c|c|c|c|c|c|c|c|c|}
\hline \multirow{3}{*}{ Item } & \multirow{3}{*}{$\begin{array}{l}\text { Material } \\
\text { type }\end{array}$} & \multicolumn{9}{|c|}{ Applied heat treatment } \\
\hline & & \multicolumn{3}{|c|}{ Annealing } & \multicolumn{3}{|c|}{ Quenching } & \multicolumn{2}{|c|}{ Tempering } & \multirow{2}{*}{$\begin{array}{c}\text { Resilience } \\
\mathrm{KCU} \\
{\left[\mathrm{J} / \mathrm{cm}^{2}\right]}\end{array}$} \\
\hline & & $\begin{array}{c}\text { Temp. } \\
{\left[{ }^{\circ}\right]}\end{array}$ & $\begin{array}{c}\text { Time } \\
\text { [hours] }\end{array}$ & Cooling & $\begin{array}{c}\text { Temp. } \\
\left.{ }^{\circ}\right]\end{array}$ & Medium & Cooling & $\begin{array}{c}\text { Temp. } \\
\left.{ }^{\circ}\right]\end{array}$ & Cooling & \\
\hline 1 & \multirow{4}{*}{$40 \mathrm{Cr} 130$} & \multirow{4}{*}{750} & \multirow{4}{*}{1.5} & \multirow{4}{*}{ furnace } & \multirow{2}{*}{1000} & \multirow{2}{*}{ vacuum } & \multirow{2}{*}{$\begin{array}{c}\text { Recirculated } \\
\text { nitrogen }\end{array}$} & 150 & nitrogen & 10.2 \\
\hline 2 & & & & & & & & 510 & nitrogen & 8.9 \\
\hline 3 & & & & & \multirow{2}{*}{1050} & \multirow{2}{*}{ vacuum } & \multirow{2}{*}{$\begin{array}{c}\text { Recirculated } \\
\text { nitrogen }\end{array}$} & 150 & nitrogen & 14.5 \\
\hline 4 & & & & & & & & 510 & nitrogen & 8.7 \\
\hline
\end{tabular}

At temperatures above $450{ }^{\circ} \mathrm{C}, 40 \mathrm{Cr} 130$ steels are susceptible to tempering brittleness; in general, upon tempering, this phenomenon is avoided by bypassing the dangerous range, between $480-600{ }^{\circ} \mathrm{C}$, a situation that is applied to parts subjected to shock stresses during use.

Table 4 shows that the tempering in this range leads to a decrease in resilience by $15-20 \%$.

The shock resistance is also influenced by the cryogenic temperatures applied after the complete heat treatment. It is considered that the intense lowering of the temperature generates in the matrix of the material important internal stresses, which lead to the formation of microfissures as they act in a stiffened volume. Their existence leads to a certain embrittlement of the steel, exemplified by the decrease of the fracture energy.

The experimental tests conducted to highlight the influence of cryogenic temperatures focused on two working temperatures, i.e.- $85^{\circ} \mathrm{C}$ and $-196{ }^{\circ} \mathrm{C}$, respectively, as in Table 5; the specimens were fractured at ambient temperature or at $-85^{\circ} \mathrm{C}$. 
Significant variations in resilience were found, influenced by the subcooling conditions, as well as by the test conditions.

Table 5. Resilience values following the cryogenic treatment

\begin{tabular}{|c|c|c|c|c|c|c|c|c|}
\hline \multirow[b]{2}{*}{ Item } & \multirow[b]{2}{*}{$\begin{array}{l}\text { Material } \\
\text { type }\end{array}$} & \multicolumn{2}{|c|}{ Heat treatment } & \multicolumn{4}{|c|}{ Cryogenic treatment } & \multirow{2}{*}{$\begin{array}{c}\text { Resilience } \\
\mathrm{KCU} \\
{\left[\mathrm{J} / \mathrm{cm}^{2}\right]}\end{array}$} \\
\hline & & $\begin{array}{c}\text { Quenching } \\
{\left[{ }^{\circ}\right]}\end{array}$ & $\begin{array}{c}\text { Tempering } \\
{\left[^{\circ}\right]}\end{array}$ & $\begin{array}{c}\text { Cooling } \\
\text { temperature } \\
{\left[{ }^{\circ}\right]} \\
\end{array}$ & $\begin{array}{l}\text { Holding } \\
\text { [min] }\end{array}$ & $\begin{array}{l}\text { Cooling } \\
\text { medium }\end{array}$ & $\begin{array}{c}\text { Test } \\
\text { temperature } \\
{\left[{ }^{\circ}\right]} \\
\end{array}$ & \\
\hline 1 & \multirow{5}{*}{$40 \mathrm{Cr} 130$} & \multirow{5}{*}{1050} & \multirow{5}{*}{510} & $-85 \ldots-90$ & 30 & $\begin{array}{c}\text { Liquid } \\
\text { nitrogen }\end{array}$ & 20 & 8.7 \\
\hline 2 & & & & $-85 \ldots-90$ & 30 & $\begin{array}{c}\text { Liquid } \\
\text { nitrogen }\end{array}$ & -80 & 8.3 \\
\hline 3 & & & & $-85 \ldots-90$ & 5 & $\begin{array}{c}\text { Liquid } \\
\text { nitrogen }\end{array}$ & -80 & 8.5 \\
\hline 4 & & & & -196 & 30 & $\begin{array}{c}\text { Liquid } \\
\text { nitrogen }\end{array}$ & -80 & 3.4 \\
\hline 5 & & & & -196 & 5 & $\begin{array}{c}\text { Liquid } \\
\text { nitrogen }\end{array}$ & -80 & 5.4 \\
\hline
\end{tabular}

\section{Conclusions}

The experimental tests performed revealed as follows:

- The heating temperature in the annealing range influences the grain size and the degree of carbide development; this fact determines the hardness, by increasing it with the regime temperature while the resilience decreases;

- The final heat treatment gives different results depending on the heat hardening and tempering parameters. For this steel, the hardness increases with the return temperature, a phenomenon attributed to precipitation processes, while the resilience decreases markedly;

- The studies conducted for transformations generated by deep subcooling on the shock resistance revealed the importance of the preliminary and final heat treatment regimens; there was also found the effect of the subcooling temperatures, its duration as well as the temperature at which the stress occurs.

\section{References}

1. Geru N., et al. (1991): Analiza structurii materialelor metalice (Structure analysis of metallic materials). Editura Tehnică, ISBN 9733102822, București, Romania (in Romanian)

2. Giacomelli I, Druga L., Samoila C., Bot D. (2000): Tehnologii neconvenționale cu transformari de fază (Unconventional technologies with phase transformations). Editura Lux Libris, ISBN 9739428115, Brasov, Romania (in Romanian)

3. Popescu N., Gheorghe C., Popescu O. (1990): Tratamente termice neconventionale (Unconventional heat treatment). Editura Tehnică, București, ISBN 9733101826, Romania (in Romanian)

4. Li S., Xiao M., Ye G., Zhao K., Yang M. (2018): Effects of deep cryogenic treatment on microstructural evolution and alloy phases precipitation of a new low carbon martensitic stainless bearing steel during aging. Materials Science and Engineering: A, ISSN 0921-5093, Vol. 732, p. 167-177, https://doi.org/10.1016/j.msea.2018.07.012

5. Prieto G., Perez Ipiña J.E., Tuckart W.R. (2014): Cryogenic treatments on AISI 420 stainless steel: Microstructure and mechanical properties. Materials Science and Engineering: A, ISSN 0921-5093, Vol. 605, p. 236-243, https://doi.org/10.1016/i.msea.2014.03.059 